\title{
Paternal identity impacts embryonic development for two species of freshwater fish
}

Siddique, Mohammad Abdul Momin; Linhart, Otomar; Krejszeff, Sawomir; Zarski, Daniel; Pitcher, Trevor E.; Politis, Sebastian Nikitas; Butts, lan

\section{Published in:}

General and Comparative Endocrinology

Link to article, DOI:

10.1016/j.ygcen.2016.07.004

Publication date:

2017

Document Version

Version created as part of publication process; publisher's layout; not normally made publicly available

Link back to DTU Orbit

Citation $(A P A)$ :

Siddique, M. A. M., Linhart, O., Krejszeff, S., Zarski, D., Pitcher, T. E., Politis, S. N., \& Butts, I. (2017). Paternal identity impacts embryonic development for two species of freshwater fish. General and Comparative Endocrinology, 245, 30-35. https://doi.org/10.1016/j.ygcen.2016.07.004

\section{General rights}

Copyright and moral rights for the publications made accessible in the public portal are retained by the authors and/or other copyright owners and it is a condition of accessing publications that users recognise and abide by the legal requirements associated with these rights.

- Users may download and print one copy of any publication from the public portal for the purpose of private study or research.

- You may not further distribute the material or use it for any profit-making activity or commercial gain

- You may freely distribute the URL identifying the publication in the public portal 


\title{
Paternal identity impacts embryonic development for two species of freshwater fish
}

\author{
Mohammad Abdul Momin Siddique ${ }^{\mathrm{a}, *}$, Otomar Linhart ${ }^{\mathrm{a}}$, Sławomir Krejszeff ${ }^{\mathrm{b}}$, Daniel Żarski ${ }^{\mathrm{b}, \mathrm{c}}$, \\ Trevor E. Pitcher ${ }^{\mathrm{d}, \mathrm{e}}$, Sebastian Nikitas Politis ${ }^{\mathrm{f}}$, Ian Anthony Ernest Butts ${ }^{\mathrm{f}}$ \\ ${ }^{a}$ University of South Bohemia in Ceske Budejovice, Faculty of Fisheries and Protection of Waters, South Bohemian Research Center of Aquaculture and Biodiversity of \\ Hydrocenoses, Research Institute of Fish Culture and Hydrobiology, Zátiši 728/II, 38925 Vodňany, Czech Republic \\ ${ }^{\mathrm{b}}$ Department of Lake and River Fisheries, Warmia and Mazury University in Olsztyn, ul. Oczapowskiego 5, PL 10-719 Olsztyn-Kortowo, Poland \\ ' Szent István University, Faculty of Agricultural and Environmental Sciences, Institute of Aquaculture and Environmental Safety, Department of Aquaculture, \\ 2100 Gödöllö, Páter K. u. 1, Hungary \\ ${ }^{\mathrm{d}}$ Department of Biological Sciences, University of Windsor, Windsor, Ontario N9B 3P4, Canada \\ ${ }^{\mathrm{e}}$ Great Lakes Institute for Environmental Research, University of Windsor, Ontario N9B 3P4, Canada \\ ${ }_{\mathrm{f}}^{\mathrm{f}}$ DTU Aqua-National Institute of Aquatic Resources, Section for Marine Ecology and Oceanography, Technical University of Denmark, Charlottenlund Slot, \\ Jægersborg Allé 1, 2920 Charlottenlund, Denmark
}

\section{A R T I C L E I N F O}

\section{Article history:}

Received 2 January 2016

Revised 2 June 2016

Accepted 7 July 2016

Available online $\mathrm{xxxx}$

\section{Keywords:}

Paternal effects

Maternal effects

Ide

Northern pike

\begin{abstract}
A B S T R A C T
Paternal, compared to maternal, contributions were believed to have only a limited influence on embryonic development and larval fitness traits in fishes. Therefore, the perspective of male influence on early life history traits has come under scrutiny. This study was conducted to determine parental effects on the rate of eyed embryos of Ide Leuciscus idus and Northern pike Esox lucius. Five sires and five dams from each species were crossed using a quantitative genetic breeding design and the resulting 25 sib groups of each species were reared to the embryonic eyed stage. We then partition variation in embryonic phenotypic performance to maternal, paternal, and parental interactions using the Restricted Maximum Likelihood (REML) model. Results showed that paternal, maternal, and the paternal $\times$ maternal interaction terms were highly significant for both species; clearly demonstrating that certain family combinations were more compatible than others. Paternal effects explained $20.24 \%$ of the total variance, which was 2 -fold higher than the maternal effects $(10.73 \%)$ in Ide, while paternal effects explained $18.9 \%$ of the total variance, which was 15 -fold higher than the maternal effects (1.3\%) in Northern pike. Together, these results indicate that male effects are of major importance during embryonic development for these species. Furthermore, this study demonstrates that genetic compatibility between sires and dams plays an important role and needs to be taken into consideration for reproduction of these and likely other economically important fish species.
\end{abstract}

(c) 2016 Elsevier Inc. All rights reserved.

\section{Introduction}

Parental effects on early life history (ELH) traits of fish (i.e. eggs to small juveniles) are widely recognized (Heath and Blouw, 1998). The driving force behind each parental contribution is likely to be strongly modified by genotype, environmental effects, as well as the interaction between genes and the environment (Conover, 1998; Neff and Pitcher, 2005; Politis et al., 2014). As a result, understanding factors that influence the viability of offspring during early life is critical for aquaculture as well as fisheries science

\footnotetext{
* Corresponding author.

E-mail addresses: siddique@frov.jcu.cz, tigermomin@yahoo.com (M.A.M. Siddique).
}

and management, as survival during these life history stages can vary dramatically and ultimately influence commercial production and year-class strength for any given species (Bromage et al., 1992; Nagler et al., 1999).

Paternal contributions were believed to have only a limited influence on embryonic development and larval fitness traits in fishes as compared to maternal contributions (Keckeis et al., 2000; Marteinsdottir and Begg, 2002). Paternal contributions to progeny are solely the product of nuclear-genetic material from the spermatozoon (Rideout et al., 2004). Therefore, the perspective of male influence on ELH traits has come under scrutiny (Trippel, 2003; Rideout et al., 2004). Nevertheless, in the last few decades, a number of studies have demonstrated that paternal genetic 
effects contribute to variation in morphology and performance during ELH of both marine and freshwater fishes (Vøllestad and Lillehammer, 2000; Rideout et al., 2004; Pitcher and Neff, 2007; Butts and Litvak, 2007a,b; Houde et al., 2015). For instance, paternal effects on ELH traits have been demonstrated for Atlantic salmon Salmo salar (Thorpe and Morgan, 1978; Houde et al., 2015), brown trout Salmo trutta (Vøllestad and Lillehammer, 2000), rainbow trout Oncorhynchus mykiss (Rinchard et al., 2003), chinook salmon Oncorhynchus tshawytscha (Pitcher and Neff, 2007), masu salmon Oncorhynchus masou (Yamamoto and Reinhardt, 2003), herring Clupea harengus (Panagiotaki and Geffen, 1992; Evans and Geffen, 1998), European sea bass Dicentrarchus labrax (Saillant et al., 2001), haddock Melanogrammus aeglefinus (Rideout et al., 2004), winter flounder Pseudopleuronectes americanus (Butts and Litvak, 2007a,b), Trinidadian guppy Poecilia reticulata (Reynolds and Gross, 1992), alpine whitefish Coregonus sp. (Wedekind et al., 2001) and Atlantic cod Gadus morhua (Butts et al., 2009; Kroll et al., 2013; Politis et al., 2014).

Maternal contributions to progeny are the product of both nuclear-genetic material and extra-nuclear non-genetic environmentally influenced material (Rideout et al., 2004; Neff and Pitcher, 2005). The underlying cause of maternal effects include (among others) female age, female size, broodstock nutrition (Lavens et al., 1999; Furuita et al., 2000; Morehead et al., 2001), photoperiod manipulation (Watanabe et al., 2001), habitat quality (Perry et al., 1991), time of reproduction in the spawning season (Buckley et al., 2000), and hormonal-induced ovulation (Harmin and Crim, 1992). Together, these factors result in variation in egg quality (Chambers and Leggett, 1996; Chambers, 1997; Marteinsdottir and Steinarsson, 1998; Rideout et al., 2005). Because of these aforementioned processes, maternal contributions are generally considered more important than paternal influences (Trippel, 2003; Rideout et al., 2004), as good quality eggs are considered a prerequisite for the production of viable offspring, especially during the "critical" ELH stages (Trippel et al., 1997).

For this study we use two different species, Ide Leuciscus idus L., and Northern pike, Esox lucius. Ide, is a rheophileous cyprinid, widely distributed in Europe, especially in rivers and lakes (Jamróz et al., 2008; Cejko et al., 2010; Ciesla et al., 2014). In recent years, reproduction of Ide in captivity has received increasing attention to meet the demand of high quality juveniles for restocking (Wojda, 2004; Krejszeff et al., 2009), sport fishing, aquarium industry (Jamróz et al., 2008; Cejko et al., 2010), toxicity studies (Witeska et al., 2014) and as a bio-monitoring agent (Fenske et al., 2006). On the other hand, Northern pike is an iteroparous, large-bodied and long-living ( $>10$ years) fish species inhabiting the northern hemisphere (Craig, 2008; Forsman et al., 2015). There is interest in fishing this species but it has also been cultivated extensively in Europe and Asia since the middle ages (Steinberg, 1992). Males and females sexually mature at the age of 2-3 and 3-4 years, respectively. Females and males swim through and over the vegetation in water and release eggs and sperm simultaneously at irregular intervals for up to several hours (Froese and Pauly, 2015).

The objective of this study was to determine the effect of genetic compatibility and/or incompatibility during embryonic development for Ide and Northern pike. More specifically, we crossed 5 females with 5 males, in a quantitative genetic breeding design and reared the resulting 25 sib groups of each species (in replicate) to the embryonic eyed stage. We then attempt to attribute variation in embryonic phenotypic performance to maternal, paternal, and parental interactions.

\section{Materials and methods}

\subsection{Broodstock husbandry and gamete collection for Ide}

Wild-caught Ide broodstock (age 1-3 years and weight $700 \mathrm{~g}$ to $2 \mathrm{~kg}$ ) were collected from an earthen pond from Żurawia Fish Farm (Central Poland) in the middle of April 2015. In total, 13 males and 12 females were kept separately in a recirculating aquaculture system (1000 dm $\mathrm{d}^{3}$ volume) at $10^{\circ} \mathrm{C}$ and under a $14 \mathrm{~h}$ light $/ 10 \mathrm{~h}$ dark photoperiod for two weeks (Kujawa et al., 1999). Mature males were recognized by gentle abdominal pressure and females were selected by assessing the maturation stage with catheterization according to Krejszeff et al. (2009). Males and females were stimulated with Ovopel (Interfish, Hungary) containing mammalian GnRH analogue and metoclopramide as a dopamine antagonist. One ovopel pellet (50-55 mg) contains a mammalian GnRH analogue (D-ala ${ }^{6}$, Pro ${ }^{9} \mathrm{Net}-\mathrm{mGnRH}$ at dose $25 \mathrm{mg}$ ) and dopamine antagonist: metoclopramide (dose 8-10 mg) (Horvath et al. 1997). Prior to administration, Ovopel pellets were homogenized in a mortar and dissolved in $0.9 \% \mathrm{NaCl}$ solution $(10 \mathrm{~mL}$ physiological solution for 10 pellets) following methods of Siddique et al. (2016).

For spermiation, each male received a single dose of $1 \mathrm{~mL}$ ovopel solution $\mathrm{kg}^{-1}$ body weight, intraperitoneally under the left pectoral fin. Ovulation was induced by an initial injection of $0.2 \mathrm{~mL}$ ovopel solution $\mathrm{kg}^{-1}$ body weight and a second injection of $1 \mathrm{~mL}$ ovopel solution $\mathrm{kg}^{-1}$ body weight $12 \mathrm{~h}$ after the first injection. Ripe gamete donors were anaesthetized in a solution of 2-phenoxyethanol $\left(0.5 \mathrm{~mL} \mathrm{~L}^{-1}\right)$. Milt was collected from the genital papilla under abdominal pressure avoiding contamination with urine, using a $5 \mathrm{~mL}$ plastic syringe. Until the beginning of the experiments stripped milt was stored at $4{ }^{\circ} \mathrm{C}$ for $30 \mathrm{~min}$. Females were checked every $2 \mathrm{~h}$ between 30 and $36 \mathrm{~h}$ after injection. After $36 \mathrm{~h}$ of hormonal stimulation, ovulated oocytes were collected by abdominal pressure and stored in $250 \mathrm{~mL}$ plastic containers at $4{ }^{\circ} \mathrm{C}$ until used for fertilization.

\subsection{Broodstock and gamete collection for Northern pike}

For Northern pike, $\sim 30$ males and 20 females (age $1-3$ years and weight $1-3 \mathrm{~kg}$ ) were caught by gillnet from Kortowskie Lake (Olsztyn, North-East Poland) during the spawning season (at the beginning of April 2015). Without hormonal stimulation, gametes were collected from wild-caught Northern pike broodstock. Males and females were separated by physical observation on abdomen and genital papilla. Male and female fish were stripped in the field near the lake. Naturally ovulating males were stripped first. Milt from 11 males were collected from the genital papilla under abdominal pressure avoiding contamination with urine, using a $5 \mathrm{~mL}$ plastic syringe. Among 20 females, we obtained ovulated oocytes from 8 females. Eggs were collected by abdominal pressure and stored in $250 \mathrm{~mL}$ plastic containers. Sperm and eggs both were kept in an ice box in order to transfer them to the laboratory and stored at $4{ }^{\circ} \mathrm{C}$ until used for fertilization.

\subsection{Experimental design for Ide}

The fish used in this experiment were randomly chosen and crossed using a full factorial (North Carolina II) breeding design ( 5 sires $\times 5$ dams) with 3 replicate crosses per family combination. Freshwater $\left(5 \mathrm{~mL}, 15^{\circ} \mathrm{C}, \mathrm{pH} 7.2\right)$, as an activating medium, was first placed in 75 glass petri dishes. Eggs from each female were fertilized by the sperm from each male with 3 replicates. Eggs $(\sim 100 ; 0.15 \mathrm{~g})$ were gently added to each petri dish so that they 
could be spread throughout the dish. Then, $10 \mu \mathrm{L}$ of milt were immediately added to the eggs using a micropipette. After insemination, petri dishes were shaken by hand for $20 \mathrm{~s}$ to facilitate fertilization.

Following fertilization, all the petri dishes containing eggs were kept in a $300 \mathrm{~L}$ incubation tank at $15.6^{\circ} \mathrm{C}$ with continuous water flow for 5 days. After 5 days of incubation, all the petri dishes were gently removed from the incubation tank and digital images were taken under a stereoscopic microscope (SteREO Discovery.V20, Zeiss) at $4.7 \times$ mag to count the number of eyed embryos. The percentage of eyed embryos $\left(E_{\mathrm{r}}\right)$ was then calculated for each treatment from the total number of eggs $\left(E_{\mathrm{t}}\right)$ placed in the petri dish minus dead eggs $\left(E_{\mathrm{d}}\right)$ by the following equation:

$E_{r}=\left[\left(E_{t}-E_{d}\right) / E_{t}\right] \times 100$

\subsection{Experimental design for Northern pike}

As above, the fish used in this experiment were randomly chosen and crossed using a full factorial (North Carolina II) breeding design ( 5 sires $\times 5$ dams) with 3 replicate crosses per family combination. Freshwater $\left(10 \mathrm{~mL}, 10^{\circ} \mathrm{C}, \mathrm{pH} 7.2\right)$, as an activating medium, was first placed in 75 glass petri dishes. Eggs $(\sim 140 ; 1 \mathrm{~g})$ were gently added to petri dishes and spread throughout the dish with a plastic spoon. Then, $10 \mu \mathrm{L}$ of milt was immediately added to the eggs using a micropipette. After insemination, petri dishes were shaken by hand for $20 \mathrm{~s}$ to facilitate fertilization.

Following fertilization, all petri dishes containing eggs were kept in a $1000 \mathrm{~L}$ incubation tank at $10^{\circ} \mathrm{C}$ with continuous water flow for 5 days. After 5 days of incubation, all the petri dishes were gently removed from the incubation tank and digital images were taken under a stereoscopic microscope (SteREO Discovery.V20, Zeiss) at $2.5 \times$ mag to count the number of eyed embryos. The percentage of eyed embryos $\left(E_{\mathrm{r}}\right)$ was then calculated for each treatment, as above.

\subsection{Sperm analysis}

Sperm analysis was done with the use of milt collected from 5 males of each species. Sperm quality was estimated on the basis of sperm motility parameters analyzed with a computer assisted sperm analysis (CASA) system (Sperm Class Analyzer v. 4.0.0. by Microptic S.L., Barcelona, Spain). The concentration of sperm was determined using the spectrophotometric method (Ciereszko and Dabrowski, 1993). To measure motility, a milt sample $(1 \mu \mathrm{L})$ was

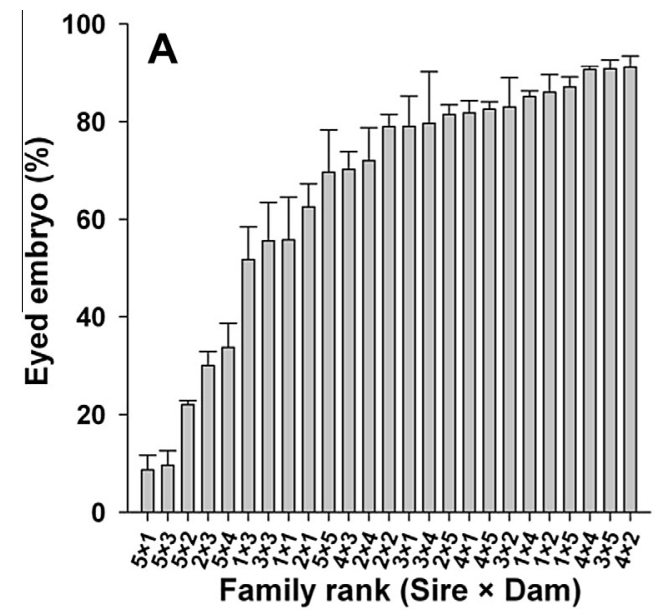

activated in freshwater $(1 \mathrm{~mL})$ and then placed on a Leja slide. Motility parameters of sperm were recorded $\sim 8 \mathrm{~s}$ after activation of motility. Analysis was done separately for each male in triplicate. For Northern pike we measured sperm density and percent motility, while for Ide we measured sperm density, percent motility, as well as curvilinear velocity, straight line velocity, and average path velocity.

\subsection{Statistical analyses}

Data were then analyzed using fullfact (Houde and Pitcher, 2016), a software program for analyzing full factorial breeding design data using mixed-effects models to extract the variance explained by random and fixed effects and provide their significance. In particular, the software integrates nonnormal error structures for estimating variance components for nonnormal data types.

\section{Results}

\subsection{Ide experiment}

The mean ( \pm SEM) sperm density of the five males was $10.8 \pm 1.6 \times 10^{9}$ cells $\mathrm{mL}^{-1}$, ranging from 6.4 to $14.9 \times 10^{9}$ cells $\mathrm{mL}^{-1}$ for Ide. The mean ( \pm SEM) percent motility of the five males was $40.8 \pm 7.2 \%$. The mean ( \pm SEM) values of curvilinear velocity, straight line velocity, and average path velocity of the sperm from all the males were $29.2 \pm 2.4$ (range: 21.6-35.3), $20.2 \pm 2.4$ (range: 13.0-25.5), and $24.0 \pm 2.6$ (range: $16.0-30.2) \mu \mathrm{m} \mathrm{s}^{-1}$, respectively.

Eyed embryo rate ranged from $8.69 \pm 3.02 \%$ to $91.15 \pm 2.24 \%$ for the 25 family crosses (Fig 1A). The full-factorial model showed that the paternal, maternal, and paternal $\times$ maternal interaction term were highly significant $(\mathrm{p}<0.0001)$ (Fig. 1B); this significant interaction term confirms that certain family combinations were

Table 1

Restricted Maximum Likelihood (REML) variance components (VC) and their associated errors (expressed as standard deviations) for the rate of eyed embryos in Ide Leuciscus idus. Each VC is also expressed as a percentage of the total variance and the significance level is reported (see Houde and Pitcher (2016) for details).

\begin{tabular}{llcl}
\hline Source of variation: ide & VC \pm SD & \%Total variance & $\mathrm{P}$ \\
\hline Maternal & $0.55 \pm 0.74$ & 10.73 & $<0.0001$ \\
Paternal & $1.04 \pm 1.02$ & 20.24 & $<0.0001$ \\
Maternal $\times$ Paternal & $0.25 \pm 0.50$ & 4.83 & $<0.0001$ \\
Residual & 3.29 & 64.19 & \\
\hline
\end{tabular}

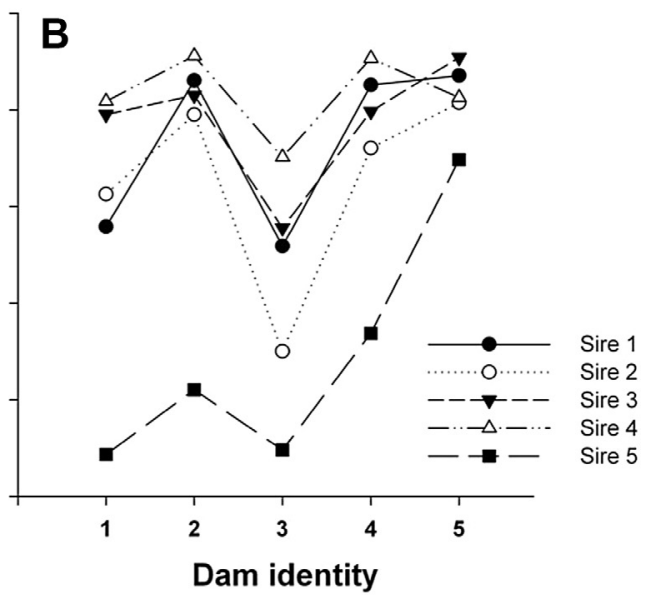

Fig. 1. Eyed embryo rate for Ide, Leuciscus idus. (A) Rate of eyed embryo for 25 family crosses; (B) interaction between sire and dam at the eyed embryo stage. 

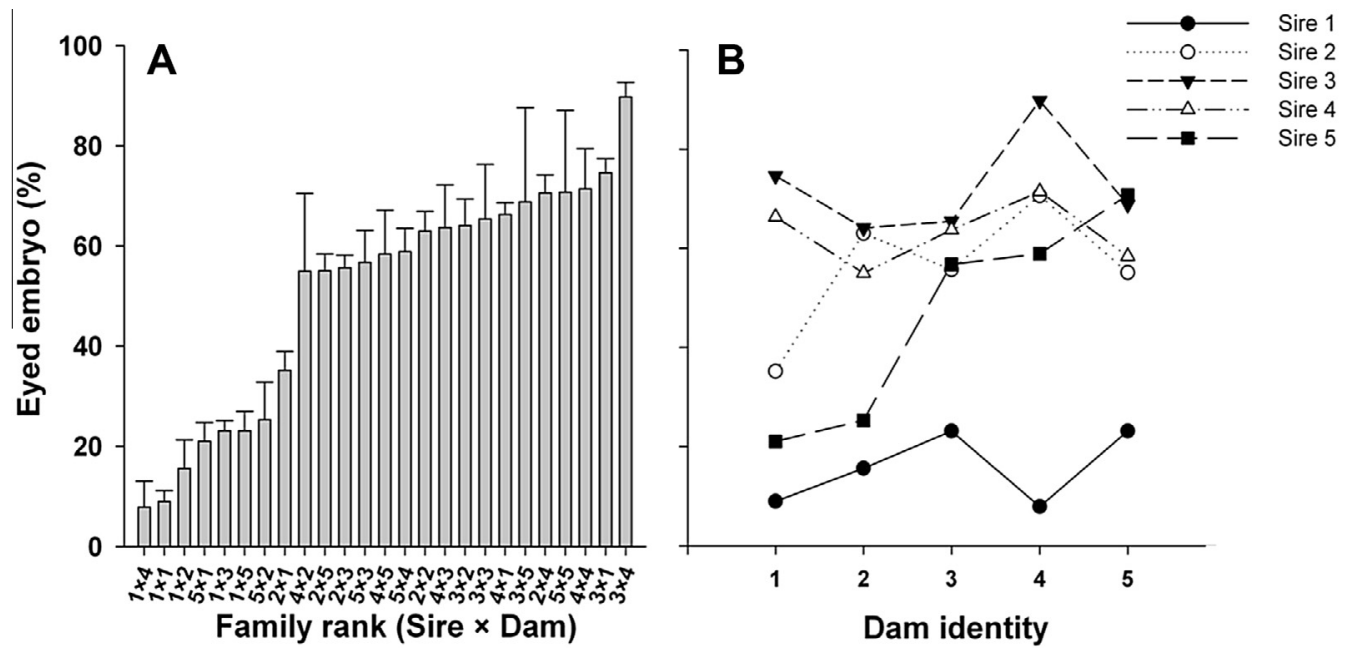

Fig. 2. Eyed embryo rate for Northern pike Esox lucius. (A) Rate of eyed embryo for 25 family crosses; (B) interaction between sire and dam at the eyed embryo stage.

Table 2

Restricted Maximum Likelihood (REML) variance components (VC) and their associated errors (expressed as standard deviations) for the rate of eyed embryos in Northern pike Esox lucius. Each VC is also expressed as a percentage of the total variance and the significance level is reported (see Houde and Pitcher (2016) for details).

\begin{tabular}{llcl}
\hline Source of variation: pike & VC \pm SD & \%Total variance & $\mathrm{P}$ \\
\hline Maternal & $0.06 \pm 0.24$ & 1.3 & $<0.0001$ \\
Paternal & $0.87 \pm 0.93$ & 18.9 & $<0.0001$ \\
Maternal $\times$ Paternal & $0.38 \pm 0.61$ & 8.3 & $<0.0001$ \\
Residual & 3.29 & 71.5 & \\
\hline
\end{tabular}

more compatible than others. Here, the paternal $(\mathrm{VC}=1.04 \pm 1.02)$, maternal $(\mathrm{VC}=0.55 \pm 0.74)$, and paternal $\times$ maternal random (VC $=0.25 \pm 0.50$ ) effects explained $20.24 \%, 10.73 \%$, and $4.83 \%$ of the total variance, respectively (Table 1 ).

\subsection{Northern pike experiment}

The mean $( \pm$ SEM) sperm density of the five males was $14.1 \pm 1.9 \times 10^{9}$ cells $\mathrm{mL}^{-1}$, ranging from 10.2 to $20.9 \times 10^{9}$ cells $\mathrm{mL}^{-1}$ for Northern pike. The mean $( \pm$ SEM) percent motility of the five males was $56.3 \pm 9.3 \%$ (range: $35.0-85.0 \%$ ).

Eyed embryo rate for Northern pike ranged from $7.87 \pm 5.12 \%$ to $89.78 \pm 2.87 \%$ for the 5 sire $\times 5$ dam factorial family crosses (Fig 2A). The model revealed that the paternal, maternal, and paternal $\times$ maternal interaction terms were significant $(\mathrm{p}<0.0001)$ (Fig. 2B). More specifically, the paternal effect $(\mathrm{VC}=0.87 \pm 0.93 ; \%$ total variance $=18.9 \%$ ) explained 14.5 and $\sim 2$ times more of the models variance than the maternal $(\mathrm{VC}=0.06 \pm 0.24$; \% total variance $=1.3 \%)$ or paternal $\times$ maternal $(\mathrm{VC}=0.38 \pm 0.61 ; \%$ total variance $=8.3 \%$ ) variance, respectively (Table 2).

\section{Discussion}

Reproductive success relies on offspring quality, which is primarily influenced by intrinsic interactions between parental genes (Neff and Pitcher, 2005; Politis et al., 2014). In the present study, we prohibited any sort of natural mate choice, i.e. reproduction involving secondary sexual characteristics and complex combinations of behaviors within and between sexes (Trippel and Morgan, 1994; Hutchings et al., 1999), by experimentally creating controlled crosses between randomly selected individuals. Here, we show that sires and dams, independently as well as interactively, had a significant impact on the rate of eyed embryos in two separate fish species. Paternal $\times$ maternal interactions explained $4.83 \%$ and $8.3 \%$ of the total variance of Ide and Northern pike, respectively. Paternal effects were $\sim 2$-fold and $\sim 15$-fold higher than the maternal effects in Ide and Northern pike respectively. Thus, paternal identity was the main driver influencing early embryonic survival to the eye stage. Furthermore, eyed embryo rate ranged from $8.69 \%$ to $91.15 \%$ for Ide and $7.87 \%$ to $89.78 \%$ for Northern pike, clearly indicating the genetic compatibility of some and incompatibility of other crosses.

Paternal effects on offspring characteristics are presumed to solely be related to the genetic (haploid) contribution, because no nutritional or energy reserves for metabolism and development of the embryo are provided by the male parent (Green, 2008). Paternal effects on early life history of teleost fishes, have in recent years gained scientific attention (Panagiotaki and Geffen, 1992; Rideout et al., 2004; Butts and Litvak, 2007b). More specifically, paternity has previously been found to affect fertilization success and time to hatch of winter flounder Pseudopleuronectes americanus, principally through parental interactions (Butts and Litvak, 2007b). Additionally, the influence of paternity was found to explain $56 \%$ and $44 \%$ of the observed variation in hatching success of Atlantic and Baltic cod, Gadus morhua, respectively (Dahlke et al., 2016). In our study, paternal influences were the predominant force influencing embryonic development for Ide and Northern pike. The results of this and the above mentioned studies validate the fact that paternity has a pronounced influence on pivotal life history traits in fish, especially for development of offspring during the critical early embryonic stages.

Maternal factors have, no doubt, a major influence on early life history traits via spawning site selection, fecundity, egg quality, egg size, and provisioning of yolk (Bengtson et al., 1987; Green, 2008). Females contribute in contrast to males, not only $50 \%$ of the nuclear genomic DNA, but also non genetic components for instance in form of a yolk and carotenoid supply (Rideout et al., 2004). Maternal factors influence initial offspring quality and size primarily by influencing egg quality and size (Bengtson et al., 1987; Chambers and Leggett, 1996; Marteinsdottir and Steinarsson, 1998). Generally, larger and older females normally produce relatively large offspring, which according to the "bigger is better hypothesis" may confer advantages to offspring during ELH (Chambers and Leggett, 1996; Trippel et al., 1997). Differences 
in the nongenetic maternal contributions might superimpose potential paternal effects, thus, a common though inadequate assumption in fish research is that most of the variation in ELH of fishes is due to maternity rather than paternity (Chambers and Leggett, 1996). Although paternal effects were in our study greater than the maternal effects for these two species, nuclear and extra nuclear maternal influences should not be disregarded.

Here we provide evidence that the optimal parental combination and their genetic compatibility increased offspring quality during embryonic development. The "genetic incompatibility hypothesis" states that offspring quality depends on the intragenomic conflicts between maternal and paternal genes (Neff and Pitcher, 2005). We observed that an egg batch of a particular female develops more successfully when sired by a compatible male, but develops poorly when sired by a less compatible (or incompatible) different male. Similar results have previously been reported from full factorial experiments with several different crossings of Alpine whitefish, Coregonus sp. (Wedekind et al., 2001) as well as Atlantic and Baltic cod (Politis et al., 2014; Dahlke et al., 2016). Common in nature and in culture, the process of polyandry, where one female reproduces with several males, enabling genetic diversity and richness, can through mate competition lead to the right mate choice and thus to higher reproductive success (Hutchings et al., 1999; Bekkevold et al., 2002). Our study clearly shows that some parental combinations are more compatible than others, resulting in higher quality offspring and thus confirms that the choice of mate does matter in order to ensure high reproductive outcome and success.

In conclusion, we demonstrate that paternally induced genetic variation during embryonic development represents a relevant resource for adaptive responses in fish. This study validates the fact that paternity and maternity act independently as well as interactively to influence ELH stages of fish. The generally accepted maternal effects were overshadowed by paternally mediated differences during embryonic development. Paternity was the main factor influencing offspring quality and coincided with a vital morphogenetic process during early life; the eyed embryo stage. Eyed embryo rate differed significantly among the different parental combinations, clearly indicating the genetic compatibility of some and incompatibility of other crosses. Thus, we provided evidence that the right female's choice of mate can result into increased offspring quality and therefore improve the chances of successful natural recruitment and/or assisted reproduction.

\section{Acknowledgments}

This study was supported by the Ministry of Education, Youth and Sports of the Czech Republic - projects "CENAKVA" (No. CZ.1.05/2.1.00/01.0024) and "CENAKVA II" (LO1205 under the NPU I program), the Grant agency of the University of South Bohemia in České Budějovice (No. 134/2013/Z), and the Grant Agency of the Czech Republic (No. 15-12034S).

\section{References}

Bekkevold, D., Hansen, M.M., Loeschcke, V., 2002. Male reproductive competition in spawning aggregations of cod (Gadus morhua, L.). Mol. Ecol. 11, 91-102.

Bengtson, D.A., Barkman, R.C., Berry, W.J., 1987. Relationships between maternal size, egg diameter, time of spawning season, temperature, and length at hatch of Atlantic silverside, Menidia menidia. J. Fish Biol. 31, 697-704.

Bromage, N., Jones, J., Randall, C., Thrush, M., Davies, B., Springate, J., Duston, J. Barker, G., 1992. Broodstock management, fecundity, egg quality and timing of egg production in the rainbow trout Oncorhynchus mykiss. Aquaculture 100, $141-166$.

Buckley, L.J., Bradley, T.M., Allen-Guilmette, J., 2000. Production, quality, and low temperature incubation of eggs of Atlantic cod Gadus morhua and haddock Melanogrammus aeglefinus in captivity. J. World Aquacult. Soc. 31, 22-29.
Butts, I.A.E., Litvak, M.K., 2007a. Parental and stock effects on larval growth and survival to metamorphosis in winter flounder (Pseudopleuronectes americanus). Aquaculture 269, 339-348.

Butts, I.A.E., Litvak, M.K., 2007b. Stock and parental effects on embryonic and early larval development of winter flounder Pseudopleuronectes americanus (Walbaum). J. Fish Biol. 70, 1070-1087.

Butts, I.A.E., Trippel, E.A., Litvak, M.K., 2009. The effect of sperm to egg ratio and gamete contact time on fertilization success in Atlantic cod Gadus morhua L. Aquaculture 286, 89-94.

Cejko, B.I., Kowalski, R.K., Kucharczyk, D., Targońska, K., Krejszeff, S., Żarski, D., Glogowski, J., 2010. Influence of the length of time after hormonal stimulation on selected parameters of milt of ide Leuciscus idus L. Aquac. Res. 41, 804-813.

Chambers, R.C., 1997. Environmental influences on egg and propagule sizes in marine fishes. In: Chambers, R.C., Trippel, E.A. (Eds.), Early Life History and Recruitment in Fish Populations, Fish and Fisheries Series. Chapman and Hall, London, pp. 63-102.

Chambers, R.C., Leggett, W.C., 1996. Maternal influences on variation in egg sizes in temperate marine fishes. Am. Zool. 36, 180-196.

Ciereszko, A., Dabrowski, K., 1993. Estimation of sperm concentration of rainbow trout, whitefish and yellow perch using a spectrophotometric technique. Aquaculture 109, 367-373.

Cieśla, M., Jończyk, R., Gozdowski, D., Śliwiński, J., Rechulicz, J., Andrzejewski, W. 2014. Changes in ide Leuciscus idus (L.) females' reproductive parameters after stimulation with carp pituitary homogenate $(\mathrm{CPH})$ and Ovopel: the effect of domestication? Aquacult. Int. 22, 77-88.

Conover, D.O., 1998. Local adaptation in marine fishes: evidence and implications for stock enhancement. Bull. Mar. Sci. 62, 477-493.

Craig, J.F., 2008. A short review of pike ecology. Hydrobiologia 601, 5-16.

Dahlke, F.T., Politis, S.N., Butts, I.A.E., Trippel, E.A., Peck, M.A., 2016. Fathers modify thermal reaction norms for hatching success in Atlantic cod, Gadus morhua. J. Exp. Mar. Biol. Ecol. 474, 148-155.

Evans, J.P., Geffen, A.J., 1998. Male characteristics, sperm traits, and reproductive success in winter-spawning Celtic Sea Atlantic herring, Clupea harengus. Mar. Biol. 132, 179-186.

Fenske, C., Daeschlein, G., Gunther, B., Knauer, A., Rudolph, P., Schwahn, C., von Woedtke, T., Rossberg, H., Julich, W.D., Kramer, A., 2006. Comparison of different biological methods for the assessment of ecotoxicological risks. Int. J. Hyg. Environ. Health 209, 275-284.

Forsman, A., Tibblin, P., Berggren, H., Nordahl, O., Koch-Schmidt, P., Larsson, P., 2015. Northern pike Esox lucius as an emerging model organism for studies in ecology and evolutionary biology: a review. J. Fish Biol. 87, 472-479.

Froese, R., Pauly, D. (Eds.), 2015. FishBase. World Wide Web Electronic Publication. Available at: www.fishbase.org, version (02/2015), (Accessed on 4 April 2015).

Furuita, H., Tanaka, H., Yamamoto, T., Shiraishi, M., Takeuchi, T., 2000. Effects of n-3 HUFA levels in broodstock diet on the reproductive performance and egg and larval quality of the Japanese flounder, Paralichthys olivaceus. Aquaculture 187, 387-398.

Green, B.S., 2008. Maternal effects in fish populations. In: Sims, D.W. (Ed.), Advances in Marine Biology, vol. 54. Elsevier Academic Press Inc., pp. 1-105.

Harmin, S.A., Crim, L.W., 1992. Gonadotropic hormone-releasing hormone analog (GnRH-A) induced ovulation and spawning in female winter flounder, Pseudopleuronectes americanus (Walbaum). Aquaculture 104, 375-390.

Heath, D.D., Blouw, D.M., 1998. Are maternal effects in fish adaptive or merely physiological side effects. In: Mouseau, T.A., Fox, C.W. (Eds.), Maternal Effects as Adaptations. Oxford University Press, New York, pp. 178-201.

Horvath, L., Szabo, T., Burke, J., 1997. Hatchery testing of GnRH analogue containing pellets on ovulation in four cyprinid species. Pol. Arch. Hydrobiol. 44, 221-226.

Houde, A.L.S., Pitcher, T.E., 2016. Fullfact: an R package for the analysis of genetic and maternal variance components from full factorial mating designs. Ecol. Evol. 6, 1656-1665.

Houde, A.L.S., Black, C.A., Wilson, C.C., Pitcher, T.E., Neff, B.D., 2015. Genetic and maternal effects on juvenile survival and fitness-related traits in three populations of Atlantic salmon. Can. J. Fish. Aquat. Sci. 72 (5), 751-758.

Hutchings, J.A., Bishop, T.D., McGregor-Shaw, C.R., 1999. Spawning behaviour of Atlantic cod, Gadus morhua: evidence of mate competition and mate choice in a broadcast spawner. Can. J. Fish. Aquat. Sci. 56, 97-104.

Jamróz, M., Kucharczyk, D., Hakuć-Błażowska, A., Krejszeff, S., Kujawa, R., Kupren, K., Kwiatkowski, M., Targońska, K., Żarski, D., Cejko, B.I., Glogowski, J., 2008. Comparing the effectiveness of Ovopel, Ovaprim, and LH-RH analogue used in the controlled reproduction of ide, Leuciscus idus (L.). Arch. Pol. Fish. 16, 363370.

Keckeis, H., Bauer-Nemeschkal, E., Menshutkin, V.V., Nemeschkal, H.L., Kamler, E., 2000. Effects of female attributes and egg properties on offspring viability in a rheophilic cyprinid, Chondrostoma nasus. Can. J. Fish. Aquat. Sci. 57, 789-796.

Krejszeff, S., Targońska, K., Żarski, D., Kucharczyk, D., 2009. Domestication affects spawning of the ide (Leuciscus idus) - preliminary study. Aquaculture 295, 145 147

Kroll, M.M., Peck, M.A., Butts, I.A.E., Trippel, E.A., 2013. Paternal effects on early life history traits in Northwest Atlantic cod, Gadus morhua. J. Appl. Ichthyol. 29, 623-629.

Kujawa, R., Kucharczyk, D., Mamcarz, A., 1999. A model system for keeping spawners of wild and domestic fish before artificial spawning. Aquacult. Eng. $20,85-89$. 
Lavens, P., Lebegue, E., Jaunet, H., Brunel, A., Dhert, P.H., Sorgeloos, P., 1999. Effect of dietary essential fatty acids and vitamins on egg quality in turbot broodstocks. Aquacult. Int. 7, 225-240,

Marteinsdottir, G., Begg, G.A., 2002. Essential relationships incorporating the influence of age, size and condition on variables required for estimation of reproductive potential in Atlantic cod Gadus morhua stocks. Mar. Ecol. Prog. Ser. $235,235-256$.

Marteinsdottir, G., Steinarsson, A., 1998. Maternal influence on the size and viability of Iceland cod Gadus morhua eggs and larvae. J. Fish Biol. 52, 12411258

Morehead, D.T., Hart, P.R., Dunstan, G.A., Brown, M., Pankhurst, N.W., 2001. Differences in egg quality between wild striped trumpeter (Latris lineata) and captive striped trumpeter that were fed different diets. Aquaculture 192, 39-53.

Nagler, J.J., Adams, B.A., Cyr, D.G., 1999. Egg production, fertility, and hatch success of American plaice held in captivity. Trans. Am. Fish. Soc. 128, 727-736.

Neff, B.D., Pitcher, T.E., 2005. Genetic quality and sexual selection: an integrated framework for good genes and compatible genes. Mol. Ecol. 14, 19-38.

Panagiotaki, P., Geffen, A.J., 1992. Parental effects on size variation in fish larvae. J. Fish Biol. 41, 37-42.

Perry, D.M., Hughes, J.B., Hebert, A.T., 1991. Sublethal abnormalities in embryos of winter flounder, Pseudopleuronectes americanus from Long Island Sound. Estuaries 14, 306-317.

Pitcher, T.E., Neff, B.D., 2007. Genetic quality and offspring performance in Chinook salmon: implications for supportive breeding. Conserv. Genet. 8, 607-616.

Politis, S.N., Dahlke, F.T., Butts, I.A.E., Peck, M.A., Trippel, E.A., 2014. Temperature, paternity and asynchronous hatching influence early developmental characteristics of larval Atlantic cod, Gadus morhua. J. Exp. Mar. Biol. Ecol. 459, 70-79.

Reynolds, J.D., Gross, M.R., 1992. Female mate preference enhances offspring growth and reproduction in a fish, Poecilia reticulata. Proc. R. Soc. Lond. B Biol. Sci. 250, 57-62.

Rideout, R.M., Trippel, E.A., Litvak, M.K., 2004. Paternal effects on haddock early life history traits. J. Fish Biol. 64, 695-701.

Rideout, R.M., Trippell, E.A., Litvak, M.K., 2005. Effects of egg size, food supply and spawning time on early life history success of haddock Melanogrammus aeglefinus. Mar. Ecol. Prog. Ser. 285, 169-180.
Rinchard, J., Lee, K.J., Czesny, S., Ciereszko, A., Dabrowski, K., 2003. Effect of feeding cottonseed meal-containing diets to broodstock rainbow trout and their impact on the growth of their progenies. Aquaculture 227, 77-87.

Saillant, E., Chatain, B., Fostier, A., Przybyla, C., Fauvel, C., 2001. Parental influence on early development in the European sea bass. J. Fish Biol. 58, 1585-1600.

Siddique, M.A.M., Linhart, O., Krejszeff, S., Żarski, D., Król, J., Butts, I.A., 2016. Effects of preincubation of eggs and activation medium on the percentage of eyed embryos in ide (Leuciscus idus), an externally fertilizing fish. Theriogenology 85 849-855.

Steinberg, D., 1992. Northern pike and muskie. CY DeCrosse Inc., p. 20.

Thorpe, J.E., Morgan, R.I.G., 1978. Parental influence on growth rate, smolting rate and survival in hatchery reared juvenile Atlantic salmon, Salmo salar. J. Fish Biol. 13, 549-556.

Trippel, E.A., 2003. Estimation of male reproductive success of marine fishes. J Northwest Atl. Fish. Sci. 33, 81-113.

Trippel, E.A., Morgan, M.J., 1994. Age-specific paternal influences on reproductive success of Atlantic cod (Gadus morhua L.) of the Grand Banks, Newfoundland. ICES Mar. Sci. Symp. 198, 414-422.

Trippel, E., Kjesbu, O.S., Solemdal, P., 1997. Effects of adult age and size structure on reproductive output in marine fishes. In: Chambers, C.R., Trippel, E.A. (Eds.), Early Life History and Recruitment in Fish Populations, Fish and Fisheries Series. Chapman and Hall, London.

Vøllestad, L.A., Lillehammer, T., 2000. Individual variation in early life-history traits in brown trout. Ecol. Freshw. Fish 9, 242-247.

Watanabe, W.O., Carroll, P.M., Daniels, H.V., 2001. Sustained, natural spawning of southern flounder Paralichthys lethostigma under an extended photothermal regime. J. World Aquacult. Soc. 32, 153-166.

Wedekind, C., Muller, R., Spicher, H., 2001. Potential genetic benefits of mate selection in whitefish. J. Evol. Biol. 14, 980-986.

Witeska, M., Sarnowski, P., Ługowska, K., Kowal, E., 2014. The effects of cadmium and copper on embryonic and larval development of ide Leuciscus idus L. Fish Physiol. Biochem. 40, 151-163.

Wojda, R., 2004. Production of stocking material of rheophilous fishes in Poland in 1995-2002: possibilities and necessities of further increases. Arch. Ryb. Pol. 12, 359-369.

Yamamoto, T., Reinhardt, U.G., 2003. Paternal effect on otolith size at emergence in masu salmon. J. Fish Biol. 62, 1226-1231. 